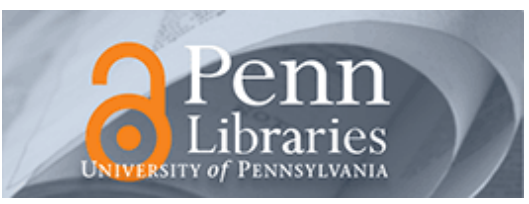

University of Pennsylvania

ScholarlyCommons

$1-12-2009$

\title{
Investigation of the Structural and Catalytic Requirements for High-Performance SOFC Anodes Formed by Infiltration of LSCM
}

\author{
Guntae Kim \\ University of Pennsylvania \\ Shiwoo Lee \\ University of Pennsylvania, shiwoo@seas.upenn.edu
}

$J$ Y. Shin

Dong-Eui University

G Corre

University of St. Andrews

J T S. Irvine

University of St. Andrews

Follow this and additional works at: https://repository.upenn.edu/cbe_papers

See next page for additional authors

\section{Recommended Citation}

Kim, G., Lee, S., Shin, J. Y., Corre, G., Irvine, J. S., Vohs, J. M., \& Gorte, R. J. (2009). Investigation of the Structural and Catalytic Requirements for High-Performance SOFC Anodes Formed by Infiltration of LSCM. Retrieved from https://repository.upenn.edu/cbe_papers/127

Investigation of the Structural and Catalytic Requirements for High-Performance SOFC Anodes Formed by Infiltration of LSCM G. Kim, S. Lee, J. Y. Shin, G. Corre, J. T. S. Irvine, J. M. Vohs, and R. J. Gorte, Electrochem. SolidState Lett. 12, B48 (2009), DOI:10.1149/1.3065971

(c) The Electrochemical Society, Inc. 2009. All rights reserved. Except as provided under U.S. copyright law, this work may not be reproduced, resold, distributed, or modified without the express permission of The Electrochemical Society (ECS). The archival version of this work was published in Electrochem. Solid-State Lett. , Volume 12, Issue 3, pp. B48-B52.

Publisher URL: http://dx.doi.org/10.1149/1.3065971

This paper is posted at ScholarlyCommons. https://repository.upenn.edu/cbe_papers/127

For more information, please contact repository@pobox.upenn.edu. 


\title{
Investigation of the Structural and Catalytic Requirements for High-Performance SOFC Anodes Formed by Infiltration of LSCM
}

\author{
Abstract \\ Composites formed by infiltration of $45 \mathrm{wt} \% \mathrm{La} 0.8 \mathrm{Sr} 0.2 \mathrm{Cr} 0.5 \mathrm{Mn} 0.503$ (LSCM) into a $65 \%$ porous yttria- \\ stabilized zirconia (YSZ) scaffold were investigated in order to understand the reasons this material is \\ able to provide excellent anode performance in solid oxide fuel cells (SOFCs). Scanning electron \\ microscopy showed that the LSCM forms a film over the YSZ after calcination at $1473 \mathrm{~K}$ but that this film \\ undergoes cracking to expose a long three-phase boundary after reduction at $1073 \mathrm{~K}$. Coulometric \\ titration demonstrated that the reduction of LSCM and La0.8Sr0.2MnO3 occurred over a similar range of \\ $\mathrm{P}(0-2)$ and that reduction is the likely cause for film cracking. To achieve low anode impedances in \\ humidified $\mathrm{H}-2$ at $973 \mathrm{~K}$, it was necessary to add a catalyst. The addition of 0.5-1 wt \% Pd, Rh, or Ni was \\ sufficient to increase the maximum power density of SOFCs with $60 \mathrm{mu}$ m thick YSZ electrolytes to $>500$ \\ $\mathrm{mW} / \mathrm{cm}(2)$ in humidified $\mathrm{H}-2$ at $973 \mathrm{~K}$. The addition of either $1 \mathrm{wt} \%$ Fe or $5 \mathrm{wt} \%$ ceria also improved \\ power densities but to a lesser extent. Finally, the use of Pt paste as the current collector increased \\ performance to a similar extent as intentionally adding catalyst, showing the importance of using inert \\ materials in electrode testing.

\section{Keywords} \\ OXIDE FUEL-CELL, METHANE OXIDATION, CERIA, PD, PEROVSKITE, REDUCTION, ZIRCONIA, CATHODES, \\ YSZ, CO2

\section{Comments} \\ Investigation of the Structural and Catalytic Requirements for High-Performance SOFC Anodes Formed by \\ Infiltration of LSCM G. Kim, S. Lee, J. Y. Shin, G. Corre, J. T. S. Irvine, J. M. Vohs, and R. J. Gorte, \\ Electrochem. Solid-State Lett. 12, B48 (2009), DOI:10.1149/1.3065971 \\ (C) The Electrochemical Society, Inc. 2009. All rights reserved. Except as provided under U.S. copyright law, \\ this work may not be reproduced, resold, distributed, or modified without the express permission of The \\ Electrochemical Society (ECS). The archival version of this work was published in Electrochem. Solid- \\ State Lett. , Volume 12, Issue 3, pp. B48-B52. \\ Publisher URL: http://dx.doi.org/10.1149/1.3065971

\section{Author(s)} \\ Guntae Kim, Shiwoo Lee, J Y. Shin, G Corre, J T S. Irvine, J M. Vohs, and Raymond J. Gorte
}




\title{
(4HS) \\ Investigation of the Structural and Catalytic Requirements for High-Performance SOFC Anodes Formed by Infiltration of LSCM
}

\author{
G. Kim, ${ }^{a}$ S. Lee, ${ }^{\text {a }}$ J. Y. Shin, ${ }^{\mathrm{b}}$ G. Corre, ${ }^{\mathrm{c}}$ J. T. S. Irvine,${ }^{\mathrm{c}, *}$ J. M. Vohs, ${ }^{\mathrm{a}, *}$ and \\ R. J. Gorte ${ }^{\mathrm{a}, *, \mathrm{z}}$ \\ ${ }^{a}$ Department of Chemical and Biomolecular Engineering, University of Pennsylvania, Philadelphia, \\ Pennsylvania 19104, USA \\ ${ }^{b}$ Department of Mechanical Engineering, Dong-Eui University, Busan 614-714, Korea \\ ${ }^{c}$ School of Chemistry, University of St Andrews, Fife KY16 9ST, Scotland
}

\begin{abstract}
Composites formed by infiltration of $45 \mathrm{wt} \% \mathrm{La}_{0.8} \mathrm{Sr}_{0.2} \mathrm{Cr}_{0.5} \mathrm{Mn}_{0.5} \mathrm{O}_{3}$ (LSCM) into a $65 \%$ porous yttria-stabilized zirconia (YSZ) scaffold were investigated in order to understand the reasons this material is able to provide excellent anode performance in solid oxide fuel cells (SOFCs). Scanning electron microscopy showed that the LSCM forms a film over the YSZ after calcination at $1473 \mathrm{~K}$ but that this film undergoes cracking to expose a long three-phase boundary after reduction at $1073 \mathrm{~K}$. Coulometric titration demonstrated that the reduction of LSCM and $\mathrm{La}_{0.8} \mathrm{Sr}_{0.2} \mathrm{MnO}_{3}$ occurred over a similar range of $\mathrm{P}\left(\mathrm{O}_{2}\right)$ and that reduction is the likely cause for film cracking. To achieve low anode impedances in humidified $\mathrm{H}_{2}$ at $973 \mathrm{~K}$, it was necessary to add a catalyst. The addition of $0.5-1 \mathrm{wt} \% \mathrm{Pd}$, Rh, or Ni was sufficient to increase the maximum power density of SOFCs with $60 \mu \mathrm{m}$ thick YSZ electrolytes to $>500 \mathrm{~mW} / \mathrm{cm}^{2}$ in humidified $\mathrm{H}_{2}$ at $973 \mathrm{~K}$. The addition of either $1 \mathrm{wt} \% \mathrm{Fe}$ or $5 \mathrm{wt} \%$ ceria also improved power densities but to a lesser extent. Finally, the use of Pt paste as the current collector increased performance to a similar extent as intentionally adding catalyst, showing the importance of using inert materials in electrode testing.
\end{abstract}

(C) 2009 The Electrochemical Society. [DOI: 10.1149/1.3065971] All rights reserved.

Manuscript submitted November 5, 2008; revised manuscript received December 10, 2008. Published January $12,2009$.

The conventional anode for solid oxide fuel cells based on yttriastabilized zirconia (YSZ) electrolytes is a composite of Ni and YSZ. ${ }^{1}$ Although the performance of these ceramic-metallic (cermet) anodes in $\mathrm{H}_{2}$ can be very good, $\mathrm{Ni}$ cermets are not redox stable, ${ }^{2}$ have relatively poor sulfur tolerance, ${ }^{3}$ and are not suitable for direct utilization of hydrocarbons in the absence of steam due to the tendency of $\mathrm{Ni}$ to catalyze the formation of carbon fibers. ${ }^{4}$ A possible remedy for each of these problems involves the development of anodes based on conducting ceramics. ${ }^{4-6}$ Until recently, the performance of ceramic anodes has been modest at lower temperatures (i.e., <1073 K); however, several recent studies have reported power densities on the order of $1 \mathrm{~W} / \mathrm{cm}^{2}$ at $1073 \mathrm{~K}$ using cells based on ceramic conductors. ${ }^{7-9}$ If these electrodes are going to find application, it will be necessary to understand the key properties that make some perform so well.

In recent work from our laboratories, excellent performance was achieved in electrodes prepared by infiltration of $\mathrm{Sr}_{0.2} \mathrm{La}_{0.8} \mathrm{Cr}_{0.5} \mathrm{Mn}_{0.5} \mathrm{O}_{3}$ (LSCM) into a porous YSZ scaffold. ${ }^{9,10}$ The anode impedance in humidified $\mathrm{H}_{2}$ at $973 \mathrm{~K}$ for an electrode made by impregnating $45 \mathrm{wt} \% \mathrm{LSCM}, 0.5 \mathrm{wt} \% \mathrm{Pd}$, and $5 \mathrm{wt} \%$ ceria into a $65 \%$ porous YSZ scaffold was $<0.1 \Omega \mathrm{cm}^{2}$. This electrode also performed well in essentially dry methane; a similar electrode with the $5 \mathrm{wt} \%$ ceria replaced by $5 \mathrm{wt} \% \mathrm{Ce}_{0.48} \mathrm{Zr}_{0.48} \mathrm{Y}_{0.04} \mathrm{O}_{2}$ $(\mathrm{CZY})$ exhibited very low impedances in $\mathrm{CO}-\mathrm{CO}_{2}$ mixtures. ${ }^{10}$ However, although the infiltrated-LSCM electrodes worked well, there are some important questions to address to understand why they work so well.

First, inspection of the electrodes by scanning electron microscopy (SEM) indicated that the LSCM forms a dense coating over the YSZ scaffold after calcination at $1473 \mathrm{~K}$, the temperature used in those studies. Because LSCM has poor ionic conductivity, a coated structure would not seem to provide the ideal three-phase boundary (TPB). Second, although the addition of the $\mathrm{Pd} /$ ceria (or Pd/CZY) catalyst was essential for reducing the electrode overpotential, it is unclear how the catalyst performs this role or what other materials might be used as replacements. For example, we made no attempt in our previous work to separate the roles of Pd and ceria. For the catalytic-reforming and water-gas-shift reactions, interactions be-

* Electrochemical Society Active Member

z E-mail: gorte@seas.upenn.edu tween Pd and ceria lead to large enhancements in activity compared to either Pd or ceria individually. ${ }^{11-13}$ Because a similar enhancement in electrode performance was observed following addition of catalytic amounts of $\mathrm{Pd} /$ ceria to an electrode prepared by infiltration $\mathrm{La}_{0.3} \mathrm{Sr}_{0.7} \mathrm{TiO}_{3}$ (LST), ${ }^{14}$ it would appear that specific interactions between the catalyst and LSCM are not required for enhanced performance. Yet, Pd is known to react with some perovskites to form highly active oxidation catalysts, ${ }^{15,16}$ so that there is a question regarding whether other catalytically active transition metals could be used in place of the Pd. ${ }^{17}$

The present work set out to address these issues. In regard to the LSCM microstructure, we will show that the LSCM is partially reduced under anode operating conditions and that this leads to the formation of cracks in the LSCM layer. This spontaneous formation of likely TPB sites appears to form an almost ideal structure for the electronic component of the electrode. In regard to catalytic requirements, it is found that ceria can provide oxidation activity but is not essential for achieving high electrode performance. Almost any metal with catalytic activity for oxidation reactions, including at least $\mathrm{Pd}, \mathrm{Rh}, \mathrm{Ni}$, and $\mathrm{Fe}$, can significantly promote electrode performance. Because the presence of catalytic metals can have such a profound influence on the electrode performance, Pt should not be used for current collection when testing ceramic anodes.

\section{Experimental}

Fuel cells were prepared using an approach similar to that discussed in previous publications. ${ }^{9,10}$ The initial step involved preparation of YSZ wafers that had two porous layers separated by a $60 \mu \mathrm{m}$ thick dense electrolyte layer. The three-layer wafers were produced by laminating three green ceramic tapes, synthesized by tape casting, with pore formers in the two outer tapes. The laminated tapes were fired to $1773 \mathrm{~K}$ to produce the final ceramic structures. The porous layer on one side of the electrolyte was $300 \mu \mathrm{m}$ thick ( $\sim 65 \%$ porous) and was used as the scaffold for the cathodes, whereas the other porous layer was $50 \mu \mathrm{m}$ thick YSZ $(\sim 65 \%$ porous) and was used as the scaffold for the anodes. Porosity in the $300 \mu \mathrm{m}$ layer was obtained using a mixture of graphite and polystyrene pore formers (used to introduce larger pores), whereas the thinner porous layer used only graphite. ${ }^{18}$

After synthesizing the porous-dense-porous YSZ wafer, either LSCM or LST was added to the $50 \mu \mathrm{m}$ porous layer at a loading of $45 \mathrm{wt} \%$, using aqueous nitrate solutions, as described elsewhere. ${ }^{9}$ It 
was necessary to infiltrate the YSZ scaffold between 10 and 20 times, with calcination to $750 \mathrm{~K}$ between infiltration steps, in order to achieve the necessary loading. Finally, the wafers with LSCM were calcined in air to $1473 \mathrm{~K}$ and the ones with LST to $1373 \mathrm{~K}$ to produce the perovskite structures. Next, the LSF-YSZ $\left(\mathrm{La}_{0.8} \mathrm{Sr}_{0.2} \mathrm{FeO}_{3}\right)$ cathodes were prepared by impregnating the $300 \mu \mathrm{m}$ thick layer with an aqueous solution containing $\mathrm{La}\left(\mathrm{NO}_{3}\right)_{3} \cdot 6 \mathrm{H}_{2} \mathrm{O}, \mathrm{Sr}\left(\mathrm{NO}_{3}\right)_{2}$, and $\mathrm{Fe}\left(\mathrm{NO}_{3}\right)_{3} \cdot 9 \mathrm{H}_{2} \mathrm{O}$, to a loading of $40 \mathrm{wt} \% \mathrm{LSF}$, followed by calcination to $1123 \mathrm{~K} .{ }^{19,20}$ LSF-YSZ cathodes prepared in this way have been shown to exhibit an electrode impedance that is independent of current density and between 0.1 and $0.15 \Omega \mathrm{cm}^{2}$ at $973 \mathrm{~K}$ in air. ${ }^{19}$

Following the addition of LSF, catalytic materials were added to the anode layer in some of the cells by addition of aqueous solutions of the nitrate salts and then heating in air to $750 \mathrm{~K}$. For fuel cell testing, a ceramic adhesive (Aremco, Ceramabond 552) was used to attach cells to an alumina tube. For most of the cells, electrical connections were achieved using $\mathrm{Ag}$ paste and $\mathrm{Ag}$ wire at both the anode and cathode. The fuel sent to the anode was humidified (3\% $\left.\mathrm{H}_{2} \mathrm{O}\right) \mathrm{H}_{2}$, while the cathode was exposed to air. Impedance spectra were measured at open circuit, in the galvanostatic mode, using a frequency range of $0.1 \mathrm{~Hz}$ to $100 \mathrm{KHz}$ and a $10 \mathrm{mV}$ ac perturbation. The active area of the cells, equal to the anode area, was $0.35 \mathrm{~cm}^{2}$, but the area of the electrolyte and cathode were $\sim 1 \mathrm{~cm}^{2}$. For most of the fuel cell studies, Ag paste (SPI supplies, lot no. 1120912) was used for current collection at both the anode and cathode. To determine the effect of the current-collector catalytic properties, one study used Pt ink (Engelhard, A3788A) as the anode current collector.

The redox properties of the $45 \mathrm{wt} \%$ LSCM-YSZ composites were measured using coulometric titration on a sample prepared in a manner similar to that used in preparing the fuel cells. The sample for these experiments was fabricated by infiltration of the aqueous nitrate salts into a porous YSZ slab, $2 \times 2 \times 10 \mathrm{~mm}$, made from the same slurry used in the YSZ tapes. The coulometric-titration apparatus has been described previously. ${ }^{21}$ Briefly, the apparatus is simply a sealed YSZ tube with Ag-paste electrodes on both sides. After placing the sample in the tube, the $\mathrm{P}\left(\mathrm{O}_{2}\right)$ was determined from the open-circuit potential. Oxygen could be added or removed from the tube by passing a current through the same electrodes used in measuring the potential. In this study, the oxidation isotherms were obtained following sample reduction in a flowing mixture of $90 \%$ $\mathrm{N}_{2}$ and $10 \% \mathrm{H}_{2}$ for $1.5 \mathrm{~h}$ at $1023 \mathrm{~K}$. The sample was then allowed to come to equilibrium using the criterion that the potential of the oxygen sensor change by $<1 \mathrm{mV} / \mathrm{h}$. The microstructure of the LSCM was inspected by SEM on a JEOL 5600 scanning electron microscope after oxidation in air and reduction in humidified (3\% $\left.\mathrm{H}_{2} \mathrm{O}\right) \mathrm{H}_{2}$.

\section{Results}

In order to understand the role of structure, we used SEM to examine the structure of an LSCM-YSZ composite, before and after exposure, to conditions similar to that experienced by the anode under operating conditions. Figure 1a is the micrograph obtained on the composite immediately after calcination to $1473 \mathrm{~K}$. As discussed in an earlier paper, ${ }^{9}$ the LSCM forms what appears to be a dense coating over the YSZ pore structure. The fact that LSCM forms a uniform layer over YSZ suggests that there are interactions between LSCM and YSZ, similar to that observed with liquids that "wet" surfaces that have attractive interactions with the liquid. Evidence for such "wetting" phenomena have been observed for $\mathrm{La}_{0.8} \mathrm{Sr}_{0.2} \mathrm{MnO}_{3}$ (LSM) particles on a YSZ(100) crystal, where calcination at $>1423 \mathrm{~K}$ caused particles to spread over the crystal surface. $^{22}$ When the LSCM-YSZ sample was heated to $1073 \mathrm{~K}$ in humidified $\mathrm{H}_{2}\left(3 \% \mathrm{H}_{2} \mathrm{O}\right)$ for $4 \mathrm{~h}$, the SEM image changed to that shown in Fig. 1b. Even though X-ray diffraction (XRD) showed that the LSCM structure remained intact, the filmlike structure changed dramatically. After reduction, the LSCM film had broken into very
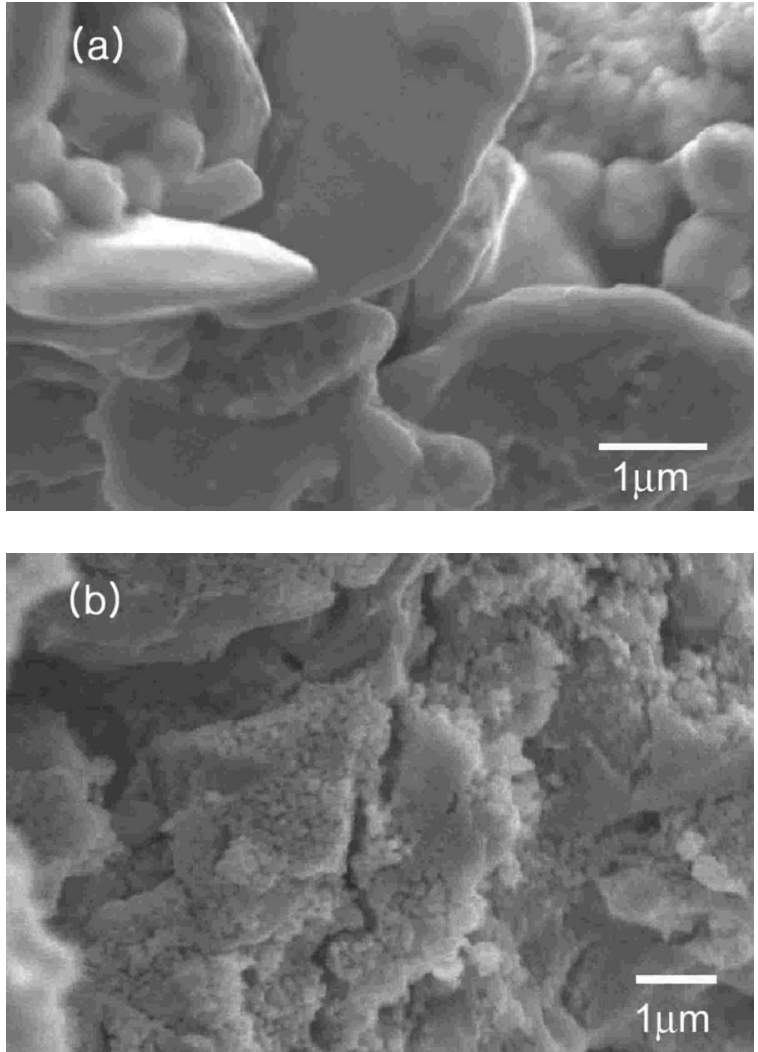

Figure 1. (a) A high-resolution SEM image of the LSCM-YSZ composite with 45 wt \% LSCM calcined at $1473 \mathrm{~K}$ in air. (b) The same composite after reduction in humidified $\mathrm{H}_{2}$ at $1073 \mathrm{~K}$ for $4 \mathrm{~h}$.

small particles, on the order of $0.1 \mu \mathrm{m}$ in size. The LSCM layer was now highly porous, suggesting that gas molecules would have access to TPB sites at the YSZ interface. Indeed, the LSCM appeared to have an almost ideal electrode structure after reduction.

The change in LSCM film structure would suggest a change in LSCM stoichiometry. In order to characterize the redox properties of LSCM in this composite structure and determine oxygen stoichiometry under anode conditions, the equilibrium oxygen content of the 45 wt \% LSCM-YSZ composite was measured as a function of $\mathrm{P}\left(\mathrm{O}_{2}\right)$ at $1023 \mathrm{~K}$ using coulometric titration. The data shown in Fig. 2 were obtained after flowing a $90 \% \mathrm{~N}_{2}-10 \% \mathrm{H}_{2}$ mixture over the sample for $1.5 \mathrm{~h}$. The $\mathrm{P}\left(\mathrm{O}_{2}\right)$ were then determined after adding increasing amounts of oxygen; the oxygen stoichiometry was assumed to be that of $\mathrm{La}_{0.8} \mathrm{Sr}_{0.2} \mathrm{Cr}_{0}{ }_{5} \mathrm{Mn}_{0.5} \mathrm{O}_{3}$ at atmospheric conditions. For comparison purposes, data for $\mathrm{La}_{0.8} \mathrm{Sr}_{0.2} \mathrm{MnO}_{3}$, reproduced from the literature, ${ }^{23}$ are also included in Fig. 2 . The data show that the equilibrium properties for LSM and LSCM are very similar in that reduction at $1023 \mathrm{~K}$ is negligible for $\mathrm{P}\left(\mathrm{O}_{2}\right)$ greater than $10^{-15} \mathrm{~atm}$ but becomes significant at lower $\mathrm{P}\left(\mathrm{O}_{2}\right)$. The big difference is that the oxygen stoichiometry decreases much more rapidly for LSM with decreasing $\mathrm{P}\left(\mathrm{O}_{2}\right)$. Indeed, it appears that $\mathrm{Mn}$ reduction occurs under similar conditions for LSM and LSCM, with the Cr in LSCM simply minimizing the extent of reduction and therefore stabilizing the structure to lower $\mathrm{P}\left(\mathrm{O}_{2}\right)$. Even so, given that a typical $\mathrm{P}\left(\mathrm{O}_{2}\right)$ under anode conditions at $1023 \mathrm{~K}$ might be $10^{-24} \mathrm{~atm}$, the oxygen stoichiometry for LSCM would be reduced from 3 to 2.86 , in reasonable agreement with prior thermogravimetric studies on LSCM powders. ${ }^{24}$ This large extent of reduction is likely responsible for the structural changes observed in Fig. 1.

To understand the catalytic requirements for LSCM-based anodes, we examined fuel cells prepared with various catalysts. In our previous work, the maximum power density for otherwise identical 


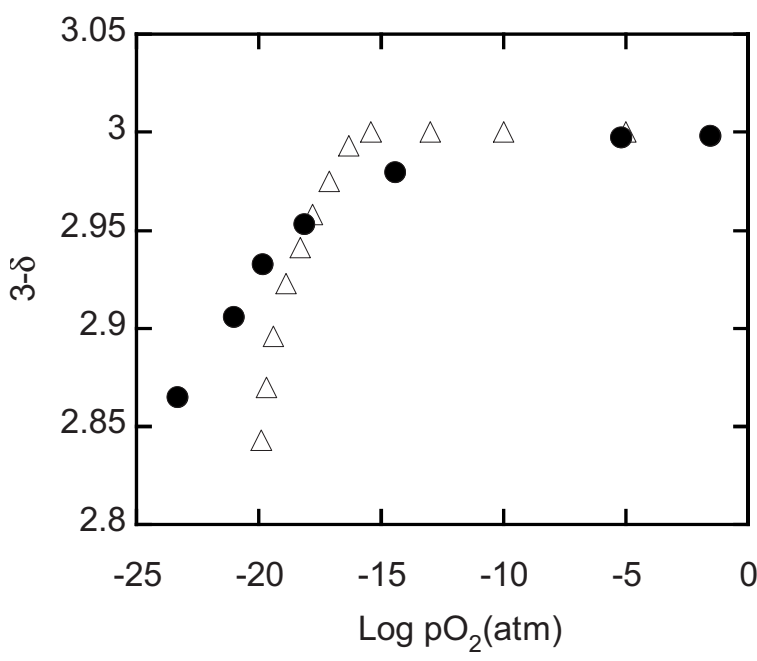

Figure 2. Equilibrium oxygen stoichiometries measured using coulometric titration at $1023 \mathrm{~K}$ for a $45 \mathrm{wt} \%$ LSCM-YSZ (๑). Data for bulk $\mathrm{La}_{0.8} \mathrm{Sr}_{0.2} \mathrm{MnO}_{3-\delta}(\mathrm{LSM})(\triangle)$, obtained from Ref. 23 are shown for comparison.

cells with anodes based on infiltrated LSCM increased by a factor of more than 10 following the addition of $0.5 \mathrm{wt} \% \mathrm{Pd}$ and $5 \mathrm{wt} \%$ ceria, when operating on humidified $\mathrm{H}_{2}$ at $973 \mathrm{~K}$. In that work, Pd and ceria were both added to the anode because ceria-supported Pd is one of the most active catalysts known for methane oxidation. ${ }^{25}$ Furthermore, Pd-ceria catalysts have been shown to exhibit activities that were much greater than that of catalysts made with either Pd or ceria individually for a number of reactions related to $\mathrm{H}_{2}$ production. ${ }^{11-13}$ Therefore, to understand the catalytic requirements in the anode, we examined fuel cells made with ceria and Pd individually and with various other oxidation catalysts. In each case, the catalysts were added to identical cells with anodes containing 45 wt \% LSCM. In all these studies, Ag paste was used for current collection.

Figure 3 provides voltage-current $(V-I)$ polarization curves at $973 \mathrm{~K}$ in humidified $\mathrm{H}_{2}$ for cells in which there was either no added catalyst, 5 wt $\%$ ceria, 0.5 wt $\% \mathrm{Pd}$, or both $5 \mathrm{wt} \%$ ceria and 0.5 wt \% Pd. The performance of the LSCM-based anode without added catalyst was much better in this study than had been observed

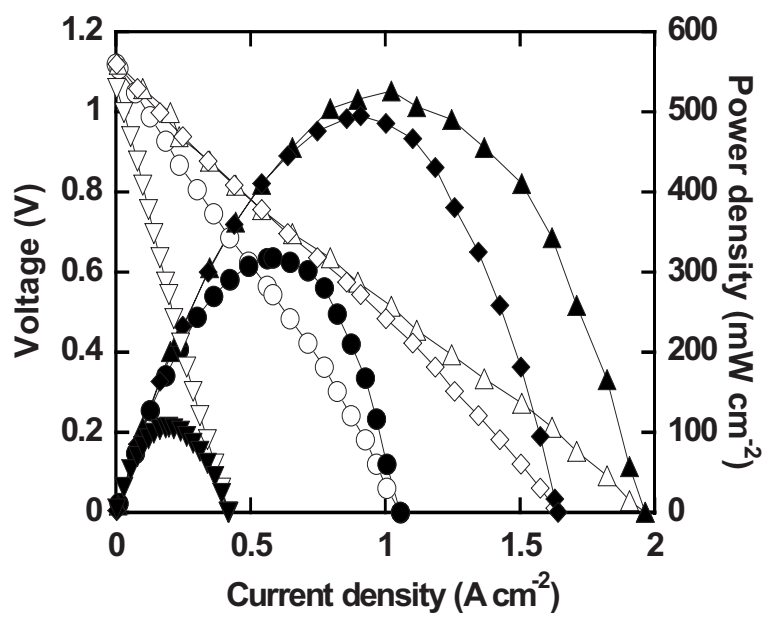

Figure 3. $V-I$ polarization curves in humidified $\mathrm{H}_{2}\left(3 \% \mathrm{H}_{2} \mathrm{O}\right)$ at $973 \mathrm{~K}$ for cells having anodes with $45 \mathrm{wt} \%$ LSCM in YSZ, using various catalysts: $(\nabla)$ no catalyst, $(\bigcirc)$ with 5 wt $\%$ ceria, $(\diamond)$ with 0.5 wt $\% \mathrm{Pd}$, and $(\triangle)$ with 5 wt $\%$ ceria and 0.5 wt $\% \mathrm{Pd}$. The filled symbols indicate the power densities.

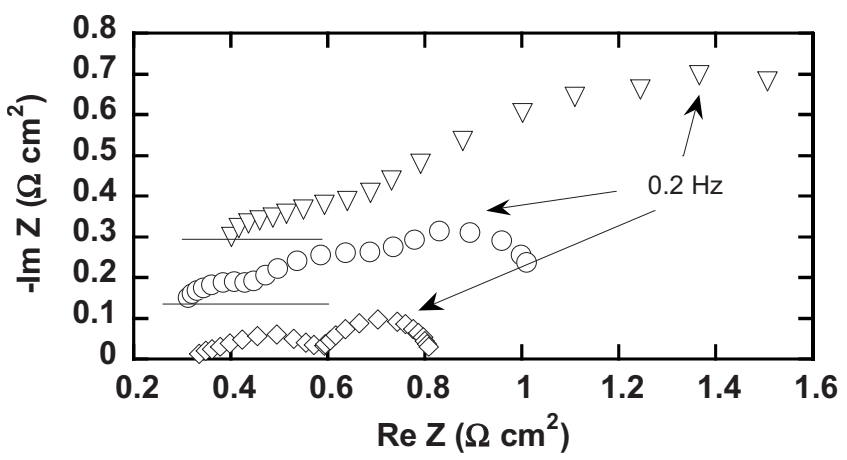

Figure 4. Impedance spectra measured at open circuit voltage (OCV) on the cells in Fig. 3: $(\nabla)$ no catalyst, $(\bigcirc)$ with 5 wt \% ceria, $(\diamond)$ with 0.5 wt \% $\mathrm{Pd}$. Only the high-frequency part of the impedance curve on the cell without catalysts is shown.

in previous work; however, the maximum power density of this cell was still only $105 \mathrm{~mW} / \mathrm{cm}^{2}$. The addition of $5 \mathrm{wt} \%$ ceria increased this to $300 \mathrm{~mW} / \mathrm{cm}^{2}$. Interestingly, the performance of the cell with only ceria added is almost identical to what was achieved in cells having a $\mathrm{Cu}$-ceria anode, with a similar YSZ-electrolyte thickness and an infiltrated LSF cathode. ${ }^{20}$ With the Cu-ceria anodes, it was argued that the $\mathrm{Cu}$ was needed primarily for electronic conductivity and that ceria provided most of the catalytic activity. ${ }^{6}$ By analogy, LSCM in the present study likely plays a similar role as that of $\mathrm{Cu}$. The most interesting result in Fig. 3 is that performance of cells with only 0.5 wt $\% \mathrm{Pd}$ and with $0.5 \mathrm{wt} \% \mathrm{Pd}$ and 5 wt $\%$ ceria was similarly good, exhibiting power densities of 500 and $520 \mathrm{~mW} / \mathrm{cm}^{2}$, respectively. Clearly, ceria is not necessary for achieving high performance in these cells.

Figure 4 shows the impedance plots corresponding to the data in Fig. 3 at open circuit for the cells without catalyst, with $5 \mathrm{wt} \%$ ceria, and with 0.5 wt \% Pd. The ohmic losses varied between 0.30 and $0.38 \Omega \mathrm{cm}^{2}$ for these three cells but were in reasonable agreement with the expected ohmic loss associated with a $60 \mu \mathrm{m}$ YSZ electrolyte, $0.32 \Omega \mathrm{cm}^{2}$. The big differences in the impedance spectra are associated with the nonohmic losses. Although there is some curvature in the $V-I$ curves near open circuit that cause the total cell impedances in Fig. 4 to be greater than the average slopes of the lines in Fig. 3, it is apparent that the electrode losses in the cell with Pd were much lower than that of the cell with ceria, which in turn were much lower than that of the cell without added catalyst.

To determine whether Pd is unique in being able to catalyze high anode performance, we prepared similar cells with either $0.5 \mathrm{wt} \%$ $\mathrm{Rh}, 1 \mathrm{wt} \% \mathrm{Ni}$, or $1 \mathrm{wt} \% \mathrm{Fe}$. Each of these transition metals is a good oxidation catalyst but with different tendencies to undergo oxidation. For example, at $973 \mathrm{~K}, \mathrm{Fe}$ is expected to form $\mathrm{FeO}$ at $\mathrm{P}\left(\mathrm{O}_{2}\right)$ above $10^{-22}$ atm, while both $\mathrm{Rh}$ and Ni should remain metallic for all realistic $\mathrm{H}_{2}: \mathrm{H}_{2} \mathrm{O}$ ratios at this temperature. The $V$-I polarization curves at $973 \mathrm{~K}$ in humidified $\mathrm{H}_{2}$ (not shown) demonstrated that the cells with either $\mathrm{Rh}$ or Ni perform as well as the cell with $\mathrm{Pd}$, with maximum power densities of $\sim 530 \mathrm{~mW} / \mathrm{cm}^{2}$. The cell with the Fe catalyst had a slightly lower maximum power density, $400 \mathrm{~mW} / \mathrm{cm}^{2}$; but this is greater than the cell with only ceria as the catalyst. The impedance data for these three cells indicated only the nonohmic contributions were affected by the different catalysts.

In principle, interactions between these catalytic metals and LSCM may be critical in maintaining metal atoms at TPB sites or in promoting reaction at those sites. To determine whether conducting oxides other than LSCM would show similar promotional effects, we examined a cell in which the LSCM was replaced with $45 \mathrm{wt} \%$ LST. A previous study with infiltrated LST demonstrated that the addition of $0.5 \mathrm{wt} \% \mathrm{Pd}$ and $5 \mathrm{wt} \%$ ceria had a similar effect in promoting performance as we observed in the LSCM cells. ${ }^{14}$ As observed with LSCM, we found that the addition of $0.5 \mathrm{wt} \% \mathrm{Pd}$ 


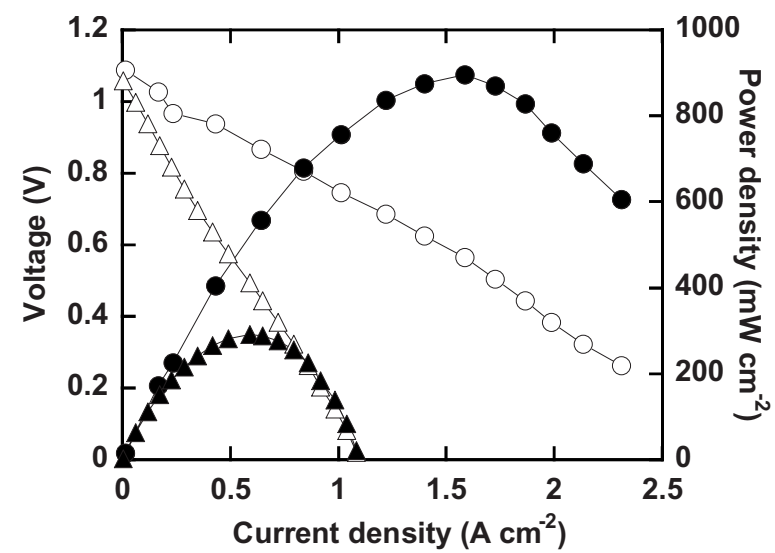

Figure 5. $V-I$ polarization curves in humidified $\mathrm{H}_{2}\left(3 \% \mathrm{H}_{2} \mathrm{O}\right)$ at $1073 \mathrm{~K}$ for cells having anodes with 45 wt \% LSCM in YSZ and no added catalyst. Data are shown using Pt paste $(\bigcirc)$ and $\operatorname{Ag}$ paste $(\triangle)$ as the current collector.

was sufficient to increase performance dramatically. For operation in humidified $\mathrm{H}_{2}$ at $973 \mathrm{~K}$, the maximum power density was $380 \mathrm{~mW} / \mathrm{cm}^{2}$ after the addition of Pd but only $3 \mathrm{~mW} / \mathrm{cm}^{2}$ in the absence of a catalyst. The power densities were somewhat lower in cells made with LST because LST does not "wet" the YSZ surface and form the same ideal electrode structure. ${ }^{14}$ The relative enhancement upon Pd addition was also greater for LST, suggesting that LSCM by itself has a somewhat higher catalytic activity. ${ }^{26,27}$

In all of the work described here, we employed an Ag current collector so as to minimize any catalytic promotion associated with this. It is common in many studies to use Pt, which obviously is a catalyst. We therefore set out to determine whether Pt paste at the anode surface might affect the anode performance. Figure 5 shows $V-I$ polarization curves for two identical cells made with infiltrated LSCM and no added catalyst, using Ag or Pt paste as the current collector. The data shown here were obtained in humidified $\mathrm{H}_{2}$ at $1073 \mathrm{~K}$ and demonstrate that the performance using the Pt current collector was dramatically better, with a maximum power density of $900 \mathrm{~mW} / \mathrm{cm}^{2}$, compared to a power density of only $290 \mathrm{~mW} / \mathrm{cm}^{2}$ when using the Ag current collector. At $973 \mathrm{~K}$, the maximum power density of the cell with $\mathrm{Pt}$ paste was $\sim 500 \mathrm{~mW} / \mathrm{cm}^{2}$, similar to that found on cells using $\mathrm{Ag}$ paste when a Pd, Rh, or Ni catalyst was added intentionally.

\section{Discussion}

The work described in this study provides important insights into why anodes formed by infiltration of LSCM and catalytic metals into porous YSZ show such good performance. First, the LSCMYSZ composite spontaneously forms an almost ideal structure near the electrolyte interface. Surface free energies are apparently responsible for causing LSCM to wet the YSZ surface under oxidizing conditions and then to form pores under reducing conditions. Indeed, the LSCM structure following reduction appears to be remarkably similar to that formed following infiltration of LSM nanoparticles in a study of infiltrated cathodes. ${ }^{22}$ The authors of that study suggested that microstructure was also nearly ideal.

The role of the added metals is also remarkable. First, the amounts of metal required to provide good electrode performance were so small that the effect must be catalytic. Electrode performance was enhanced by the addition 1 wt $\%$ or less of $\mathrm{Pd}, \mathrm{Rh}, \mathrm{Ni}$, and $\mathrm{Fe}$, and this amount of metal is incapable of providing significant conductivity within the electrode. More likely, the catalytic metals must reside near TPB sites, where they can promote the oxidation of oxygen anions coming through the electrolyte. Indeed, the location of the metal atoms is likely critical, because a recent paper from another group found that the addition of Pd to an LSCMYSZ composite had little effect on electrode performance, other than what might be expected for reforming activity on the Pd itself. ${ }^{28}$ That study used a more conventional approach to prepare the LSCM-YSZ composite, simply sintering the mixed oxides. We suggest that the difference between our two studies is due to differences in the structures of the LSCM-YSZ composites. Apparently, the metal atoms were unable to migrate to the required locations in the conventional composite.

In this regard, it is somewhat surprising that using a Pt-paste current collector, applied at the top of a $50 \mu \mathrm{m}$ thick electrode, far from the YSZ electrolyte, was equally effective as intentionally infiltrating catalytic metals. Some of the Pt must have migrated into the electrode, although we took care to avoid this. Certainly, there have been reports of migration in the case of $\mathrm{Ag}$ used for current collection in cathodes, ${ }^{29}$ although it was argued that the Ag caused deactivation in that case.

It is instructive to consider which metals promote electrode performance. In the present study, we observed that $\mathrm{Pd}, \mathrm{Rh}, \mathrm{Ni}, \mathrm{Fe}$, and $\mathrm{Pt}$ are all capable of promoting the anode. Because the Ag current collector appears to have no effect, $\mathrm{Ag}$ is not effective. In an earlier study of catalysis in a functional layer, ${ }^{17}$ it was reported that $\mathrm{Cu}$ also has limited catalytic activity. The major differences between $\mathrm{Cu}$ and $\mathrm{Ag}$ and the active metals are as follows: (i) Unlike $\mathrm{Ag}$ and $\mathrm{Cu}$, the active metals readily dissociate $\mathrm{H}_{2}$, and (ii) when used as oxidation catalysts, $\mathrm{Cu}$ and $\mathrm{Ag}$ tend to be more selective for partial oxidation with hydrocarbons, while the more active metals promote complete oxidation of hydrocarbons to $\mathrm{CO}_{2}$ and water. Both dissociation of $\mathrm{H}_{2}$ and total oxidation of the oxygen anions are likely critical for reactions at the TPB.

Clearly, both the structural and catalytic properties observed in this study have a strong influence on the electrode performance. Developing a better understanding of how these properties influence performance should allow the development of improved materials with more optimal properties.

\section{Conclusions}

Outstanding anode performance can be achieved using electrodes formed by infiltration of LSCM and catalytically active transition metals into porous YSZ. LSCM-YSZ composites formed in this way have a long TPB length due to spreading of the LSCM under oxidizing conditions and then fracturing under reducing conditions. Transition metals are required to catalyze the reaction between $\mathrm{H}_{2}$ and oxygen anions at the TPB sites.

\section{Acknowledgments}

We thank the U.S. Office of Naval Research for support for this collaboration. G.C. and J.T.S.I. also thank EPSRC for support through, Senior Fellowship, Carbon Vision and Supergen schemes. J.Y.S. acknowledges the support of Dong-Eui University Foundation Grant (2007).

University of Pennsylvania assisted in meeting the publication costs of this article.

\section{References}

1. N. Q. Minh, J. Am. Ceram. Soc., 76, 563 (1993).

2. M. Cassidy, G. Lindsay, and K. Kendall, J. Power Sources, 61, 189 (1996).

3. M. Gong, X. Liu, J. Trembly, and C. Johnson, J. Power Sources, 168, 289 (2007).

4. S. McIntosh and R. J. Gorte, Chem. Rev. (Washington, D.C.), 104, 4845 (2004).

5. A. Atkinson, S. Barnett, R. J. Gorte, J. T. S. Irvine, A. J. McEvoy, M. Mogensen, S. Singhal, and J. Vohs, Nature Mater, 3, 17 (2004)

6. M. D. Gross, J. M. Vohs, and R. J. Gorte, J. Mater. Chem., 17, 3071 (2007).

7. Y.-H. Huang, R. I. Dass, J. C. Denyszyn, and J. B. Goodenough, J. Electrochem. Soc., 153, A1266 (2006).

8. M. D. Gross, J. M. Vohs, and R. J. Gorte, Electrochem. Solid-State Lett., 10, B65 (2007).

9. G. Kim, G. Corre, J. T. S. Irvine, J. M. Vohs, and R. J. Gorte, Electrochem Solid-State Lett., 11, B16 (2008).

10. F. Bidrawn, G. Kim, G. Corre, J. T. S. Irvine, J. M. Vohs, and R. J. Gorte, Elec trochem. Solid-State Lett., 11, B167 (2008).

11. T. Bunluesin, R. J. Gorte, and G. W. Graham, Appl. Catal., B, 15, 107 (1998).

12. S. Sharma, S. Hilaire, J. M. Vohs, R. J. Gorte, and H.-W. Jen, J. Catal., 190, 199 (2000).

13. X. Wang and R. J. Gorte, Catal. Lett., 73, 15 (2001).

14. S. Lee, G. Kim, J. M. Vohs, and R. J. Gorte, J. Electrochem. Soc., 155, B1179 
(2008).

15. Y. Nishihata, J. Mizuki, T. Akao, H. Tanaka, M. Uenishi, M. Kimura, T. Okamoto, and N. Hamada, Nature (London), 418, 164 (2002).

16. J. Li, U. G. Singh, J. W. Bennett, K. Page, J. Weaver, J.-P. Zhang, T. Proffen, A. M. Rappe, S. L. Scott, and R. Seshadri, Chem. Mater, 19, 1418 (2007).

17. M. D. Gross, J. M. Vohs, and R. J. Gorte, J. Electrochem. Soc., 154, B694 (2007).

18. M. Boaro, J. M. Vohs, and R. J. Gorte, J. Am. Ceram. Soc., 86, 395 (2003)

19. W. Wang, M. D. Gross, J. M. Vohs, and R. J. Gorte, J. Electrochem. Soc., 154, B439 (2007)

20. Y. Huang, J. M. Vohs, and R. J. Gorte, J. Electrochem. Soc., 151, A646 (2004).

21. P. R. Shah, T. Kim, G. Zhou, P. Fornasiero, and R. J. Gorte, Chem. Mater, 18, 5363 (2006).

22. Y. Huang, J. M. Vohs, and R. J. Gorte, Electrochem. Solid-State Lett., 9, A237
(2006).

23. J. Mizusaki, N. Mori, H. Takai, Y. Yonemura, H. Minamiue, H. Tagawa, M. Dokiya, H. Inaba, K. Naraya, T. Sasamoto, et al., Solid State Ionics, 129, 163 (2000) 24. S. M. Plint, P. A. Connor, S. W. Tao, and J. T. S. Irvine, Solid State Ionics, 177, 2005 (2006).

25. S. Colussi, A. Trovarelli, G. Groppi, and J. Llorca, Catal. Commun., 8, 1263 (2007).

26. S. Tao, J. T. S. Irvine, and S. M. Plint, J. Phys. Chem. B, 110, 21771 (2006).

27. M. van den Bossche and S. McIntosh, J. Catal., 255, 313 (2008).

28. Y. M. Ye, T. M. He, Y. Li, E. H. Tang, T. L. Reitz, and S. P. Jiang, J. Electrochem Soc., 155, B811 (2008).

29. S. P. Simner, M. D. Anderson, L. R. Pederson, and J. W. Stevenson, J. Electrochem. Soc., 152, A1851 (2005). 